\title{
Recombinant Human Bone Morphogenetic Protein 4
}

National Cancer Institute

\section{Source}

National Cancer Institute. Recombinant Human Bone Morphogenetic Protein 4. NCI

Thesaurus. Code C131018.

A recombinant form of human bone morphogenetic protein 4 (rhBMP4; rhBMP-4), with potential antineoplastic activity. Upon administration, rhBMP4 binds to BMP receptors (BMPRs) and activates BMP-mediated signal transduction pathways. This may lead to the transcription of BMP4-targ et genes and to inhibition of the proliferation of certain tumor cell types. Additionally, rhBMP4 binding promotes the differentiation of normal stem cells and decreases both differentiation and renewal of cancer stem cells (CSCs). BMP4, an extracellular signaling molecule belonging to the transforming growth factor beta (T GFb) superfamily, plays a key role in bone formation. It also plays a role in the pathogenesis of certain cancers; BMP4 suppresses growth of certain types of cancer cells, and is also able to induce migration, invasion, and epithelial-mesenchymal transition (EMT), which may promote cancer metastasis and progression. 